\title{
In-Vivo Toxicity Assessment of Aspartame in Drosophila melanogaster and Danio rerio
}

\author{
Fahira Reshman, R. Sumitha and V . Deepa Parvathi* \\ Department of Biomedical Sciences, Sri Ramachandra University, Porur, Chennai - 600116, Tamil Nadu, India; \\ fahirazakir@gmail.com,sumithamadhu79@gmail.com, deepakoushik305@gmail.com
}

\begin{abstract}
Background/Objectives: Aspartame is a synthetic sweetener used as an alternate for sugar in food and beverages. Many research observations and findings have related to adverse health effects of aspartame. The medical symptoms include severe headache, giddiness, gastrointestinal and psychological disturbances. In the present study we have evaluated the genotoxicity of aspartame in two animal models; Drosophila melanogaster and Danio rerio. Methods: In the present study we have evaluated the genotoxicity of aspartame in two animal models; Drosophila melanogaster (Phenotypic analysis and DNA fragmentation assay) and Danio rerio (Embryo toxicity, Fin regeneration and DNA fragmentation assay). The flies and fishes were exposed to 4 concentrations of aspartame $(500 \mathrm{mg} / \mathrm{ml}, 250 \mathrm{mg} / \mathrm{ml}, 125 \mathrm{mg} / \mathrm{ml}$ and $62.5 \mathrm{mg} / \mathrm{ml}$ ). An important aspect that was considered was to measure the sugar levels (by biochemical analysis) in flies post exposure to aspartame and the same was compared with normal sugar intake and in combinations with coconut oil, sugar and aspartame. The fact of increasing blood glucose level and cholesterol levels has been a regular complaint amongst many diabetics and the usage of aspartame has also been higher in patients with diabetes. Findings: The present biochemical assay was carried out to compare and contrast the difference in glucose levels in flies exposed to increasing concentrations of sugar, oil, aspartame and combinations of sugar+ coconut oil, aspartame+ coconut oil. The results suggested marked phenotypic changes in flies and distinct shearing of DNA on DNA fragmentation assay in both flies and fishes. The extent of fin regeneration was also found to be reduced with increasing concentrations of aspartame. Embryo toxicity assay in zebra fish demonstrated inactivity, neurological disturbances followed by death. The biochemical analysis revealed the efficiency of aspartame to decrease glucose levels in hemo lymph of flies but the presence of oil hindered the efficacy of aspartame to reduce the glucose levels. Applications: The study reflects the toxicity of aspartame and brings awareness in general public about its risk in regular usage.
\end{abstract}

Keywords: Aspartame, Biochemical Analysis, Drosophila, Toxicity, Zebra Fish

\section{Introduction}

Aspartame (Molecular formula - $\mathrm{C} 14 \mathrm{H} 18 \mathrm{~N} 2 \mathrm{O} 5$ ) is a synthetic sweetener used as an alternate for sugar in food and beverages. The permissible dose of aspartame (on a daily basis) is $40 \mathrm{mg} / \mathrm{kg} \mathrm{BW}^{1-3}$. Nevertheless, habitual consumers of aspartame usually exceed this threshold. Many research observations and findings have related to adverse health effects of aspartame $e^{4-6}$, The medical symptoms include severe headache, giddiness, gastrointestinal and psychological disturbances. Certain studies have reported aggressive issues such as inborn birth defects, Alzheimer disease, Parkinson's disease and auto immune disorders ${ }^{7,8}$. The safety of aspartame has always been a topic of controversy and there are varied views regarding its usage. Studies conducted 'hitherto' have demonstrated that aspartame interferes with metabolism of amino acids and in turn disturbs protein structure and metabolism as well. Research studies on rats have shown that the neuronal function and endocrine balances have been severely compromised owing to loss of integrity of nucleic acids ${ }^{9-12}$. Studies have proved that

\footnotetext{
${ }^{*}$ Author for correspondence
} 
aspartame and its metabolic breakdown byproducts cause increased neuronal depolarization thus compromising ATP supply to enzyme reactions leading to truncated enzyme activities ${ }^{13,14}$.

\section{Materials and Methods}

\subsection{Drosophila melanogaster}

\subsubsection{Phenotypic Analysis and DNA Fragmentation Assay}

The flies (Canton $S p$ ) were reared in bottles containing corn meal medium. The flies were exposed to 4 concentrations of aspartame $(500 \mathrm{mg} / \mathrm{ml}, 250 \mathrm{mg} / \mathrm{ml}$, $125 \mathrm{mg} / \mathrm{ml}, 62.5 \mathrm{mg} / \mathrm{ml})$. The defined concentration of aspartame was mixed with the food and 30 flies (3:1 Female:male) were exposed for 72 hours and the exposure was conducted in duplicates along with control. Post exposure, the flies were subjected to phenotypic analysis under stereo zoom microscope and the changes were documented. Post phenotypic analysis, DNA was isolated from the exposed flies by phenol chloroform method and the genotoxic effect was evaluated quantitatively using DNA fragmentation assay.

\subsection{Biochemical Analysis}

Another set of flies (30/vial) were exposed to different concentrations of aspartame, sugar and coconut oil in single and in combinations $(5 \%, 10 \%, 20 \%$ of coconut oil, $2.5 \mathrm{~g}, 5 \mathrm{~g}, 10 \mathrm{~g}$ of sugar, $125 \mathrm{mg}, 250 \mathrm{mg}, 500 \mathrm{mg}$ of aspartame, $5 \%$ coconut oil +2.5 g sugar, $10 \%$ coconut oil $+5 \mathrm{~g}$ sugar, $20 \%$ coconut oil $+10 \mathrm{~g}$ sugar, $5 \%$ coconut oil+ $125 \mathrm{mg}$ aspartame, $10 \%$ coconut oil + $250 \mathrm{mg}$ aspartame, $20 \%$ coconut oil $+500 \mathrm{mg}$ aspartame) along with a negative control for a period of 5 days after which the flies were crushed using 1X PBS and centrifuged and the supernatant (haemolymph) was tested for glucose levels using hexokinase method.

\subsection{Danio rerio}

\subsubsection{Fin Regeneration Assay and DNA Fragmentation Assay}

Adult zebra fishes were maintained in specialized fish culture medium. The fishes were exposed to 4 concentration of aspartame $(500 \mathrm{mg} / \mathrm{ml}, 250 \mathrm{mg} /$ $\mathrm{ml}, 125 \mathrm{mg} / \mathrm{ml}, 62.5 \mathrm{mg} / \mathrm{ml}$ ). Young adult zebra fishes were anaesthetized with Prilox and their caudal fin was transected with a sterile surgical blade while viewing it under a stereo zoom microscope. Fishes (5 per concentration) were incubated in small culture tanks with defined concentration of aspartame dissolved in fish water for 5 days. Images were captured before and after amputation of the fin and were compared to evaluate the amount of fin regenerated. Fishes post fin regeneration assay were subjected to DNA isolation by phenol chloroform method and the genotoxic effect was evaluated quantitatively using DNA fragmentation assay.

\subsection{Embryo Toxicity Assay}

Zebra fish embryos were added into a 12 well plate (2 per well) containing fish water with varying concentrations of aspartame $(500 \mathrm{mg} / \mathrm{ml}, 250 \mathrm{mg} / \mathrm{ml}, 125 \mathrm{mg} / \mathrm{ml}, 62.5$ $\mathrm{mg} / \mathrm{ml}$ ). The results were documented and analysed. Exposure was conducted in duplicates along with control. The embryos were monitored every 8 hours with the help of a stereo zoom microscope for toxicity.

Table 1. Rate of viability and phenotypic changes observed in Drosophila melanogaster

\begin{tabular}{|c|c|c|}
\hline $\begin{array}{l}\text { Concentration of } \\
\text { aspartame }(\mathrm{mg} / \mathrm{ml})\end{array}$ & $\begin{array}{c}\text { Rate of } \\
\text { viability }(\%)\end{array}$ & Changes observed \\
\hline Negative control & 100 & No phenotypic changes \\
\hline Positive control (EMS) & 10 & Curled abdomen and orange discoloration in both males and females \\
\hline $\begin{array}{l}62.5 \mathrm{mg} / \mathrm{ml} \\
500 \mu \mathrm{l}\end{array}$ & 100 & $\begin{array}{l}\text { Curling of abdomen, shrunken thorax and orange discoloration of thorax seen in all males. } \\
\text { No phenotypic changes in females }\end{array}$ \\
\hline $\begin{array}{l}250 \mathrm{mg} / \mathrm{ml} \\
500 \mu \mathrm{l}\end{array}$ & 100 & $\begin{array}{l}\text { Curled abdomen seen in all males. } \\
\text { No phenotypic changes in females. }\end{array}$ \\
\hline $\begin{array}{l}500 \mathrm{mg} / \mathrm{ml} \\
500 \mu \mathrm{l}\end{array}$ & 100 & $\begin{array}{l}\text { All males were shrunken in size and had curled abdomen. } \\
\text { No phenotypic changes in females. }\end{array}$ \\
\hline
\end{tabular}




\section{Results}

\subsection{Drosophila Melanogaster}

\subsubsection{Phenotypic Analysis}

The phenotypic analysis in Drosophila melanogaster revealed marked phenotypic changes (curled abdomen and orange discoloration) of all the other concentrations (namely; $62.5 \mathrm{mg} / \mathrm{ml}, 125 \mathrm{mg} / \mathrm{ml}, 250 \mathrm{mg} / \mathrm{ml}$, and 500 $\mathrm{mg} / \mathrm{ml}$ ). Also noticeable changes were recorded in males compared to females. (Table 1) (Figure 1).

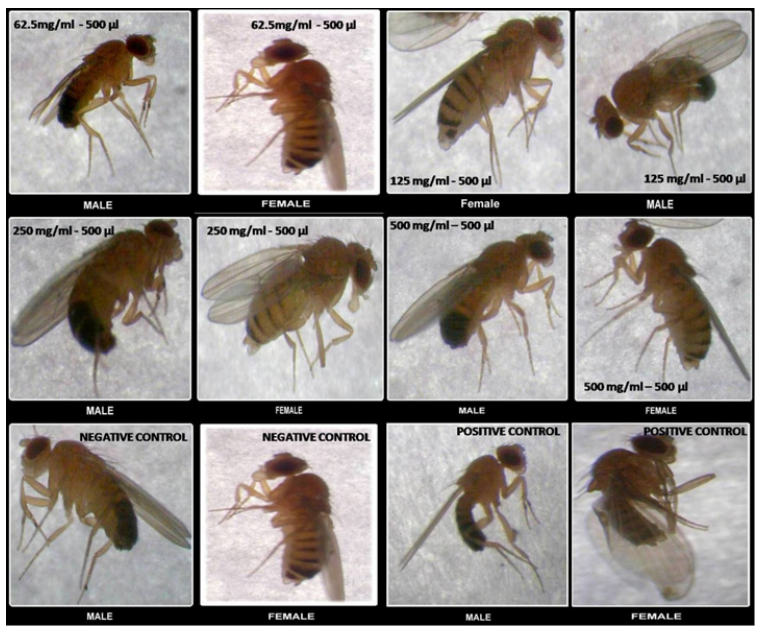

Figure 1. Phenotypic changes in Drosophila melanogaster.

Legend: Phenotypic analysis of both male and female flies exposed to concentrations of $62.5 \mathrm{mg} / \mathrm{ml}, 125 \mathrm{mg} / \mathrm{ml}, 250 \mathrm{mg} / \mathrm{ml}$ and $500 \mathrm{mg} /$ $\mathrm{ml}$ of $100 \mu \mathrm{l}$ and $500 \mu \mathrm{l}$ volumes of aspartame and negative and positive controls respectively

\subsection{DNA Fragmentation Assay}

A distinct marked increase in DNA fragmentation (observed as distinct shearing) was documented on $2 \%$ agarose with increase in concentration of aspartame (Figure 2).

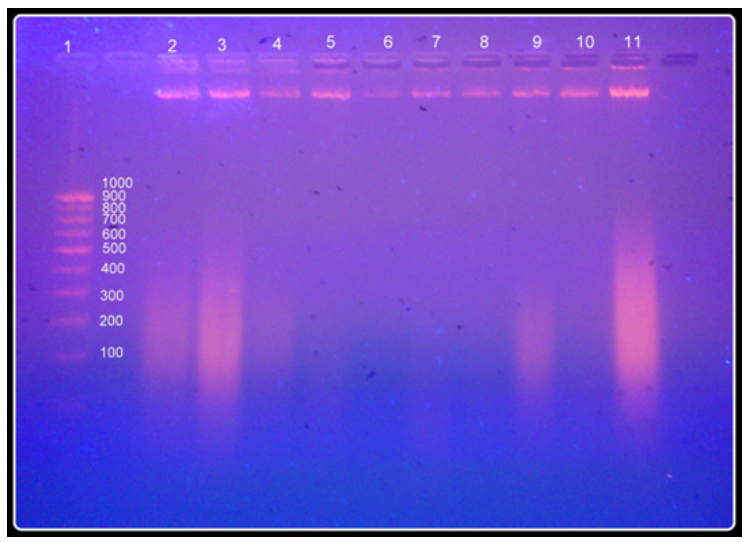

Figure 2. DNA fragmentation assay (Drosophila).

$$
\begin{aligned}
& \text { Legend: } \\
& \text { 1 - DNA ladder } \\
& 2 \text { - Negative control } \\
& 3 \text { - Positive control } \\
& 4-62.5 \mathrm{mg} / \mathrm{ml} \text { of aspartame } \\
& 5-62.5 \mathrm{mg} / \mathrm{ml} \text { of aspartame(D) } \\
& 6-125 \mathrm{mg} / \mathrm{ml} \text { of aspartame } \\
& 7-125 \mathrm{mg} / \mathrm{ml} \text { of aspartame(D) } \\
& 8-250 \mathrm{mg} / \mathrm{ml} \text { of aspartame } \\
& 9-250 \mathrm{mg} / \mathrm{ml} \text { of aspartame(D) } \\
& 10-500 \mathrm{mg} / \mathrm{ml} \text { of aspartame } \\
& 11-500 \mathrm{mg} / \mathrm{ml} \text { of aspartame(D) }
\end{aligned}
$$

\section{Coconut oil}

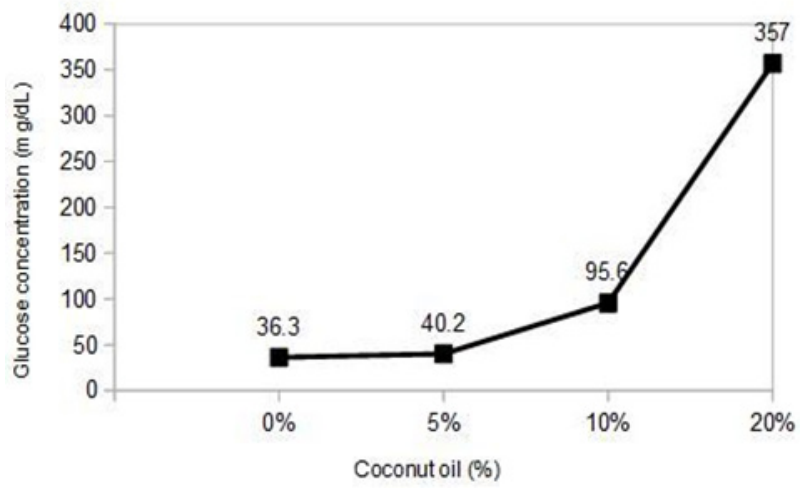

Sugar

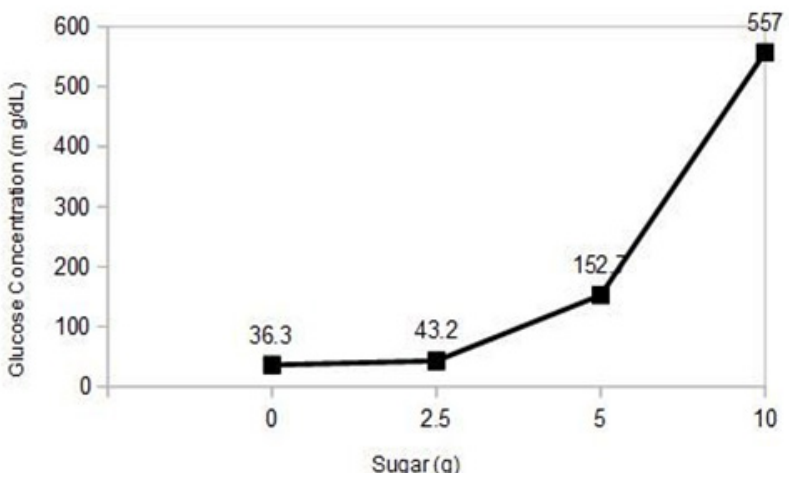

Graph 1 (left) shows Glucose concentration in hemolymph with increasing concentration of coconut oil. Graph 2 (right) shows Glucose concentration in hemolymph with increasing concentration of sugar. 

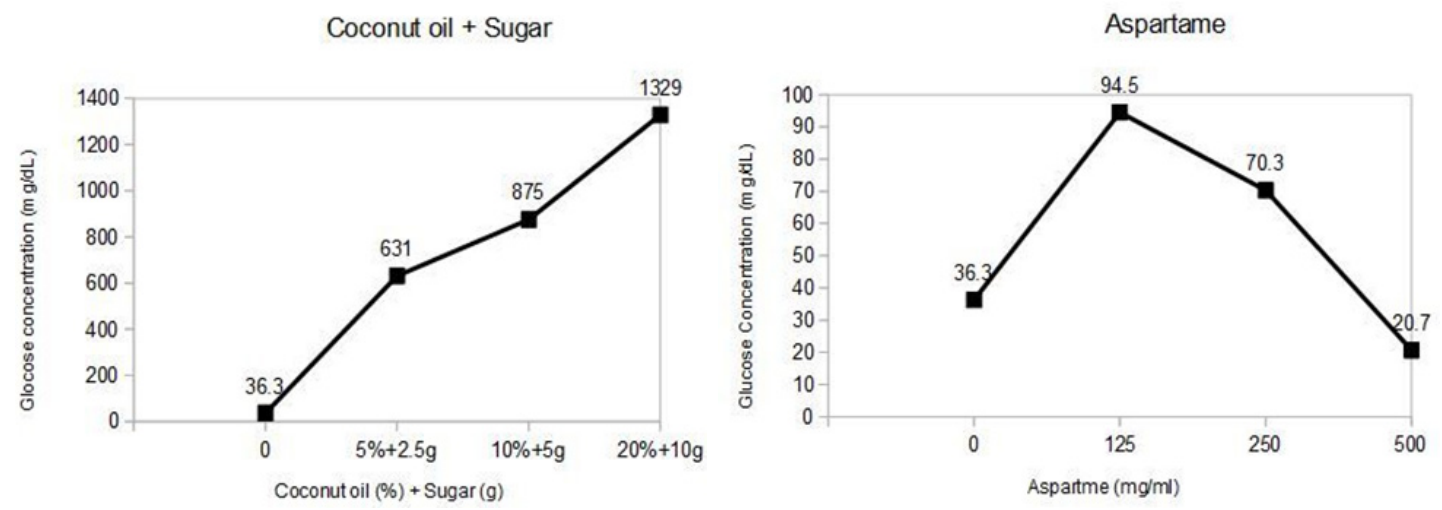

Graph 3 (left) shows Glucose concentration in hemolymph with increasing concentration of a combination of sugar and coconut oil. Graph 4 (right) shows Glucose concentration in hemolymph with increasing concentration of aspartame.

\subsection{Biochemical Analysis}

Glucose levels were analyzed using hexokinase method. The O.D. values revealed distinct increase in the glucose levels with increase in oil in diet $(20 \%$ showed maximum glucose level) (Graph 1). Increase in sugar levels proportionally increased the glucose levels (Graph 2 ). The combination of oil and sugar revealed 4 times increase in glucose levels (Graph 3). This proves the role of oil in elevating glucose levels when administered in combination with sugar.

Administration of aspartame demonstrated decrease in sugar levels (however the loss of viability to $50 \%$ were also noted at higher concentration of $500 \mathrm{mg} / \mathrm{ml}$ ) (Table 2) (Graph 4).

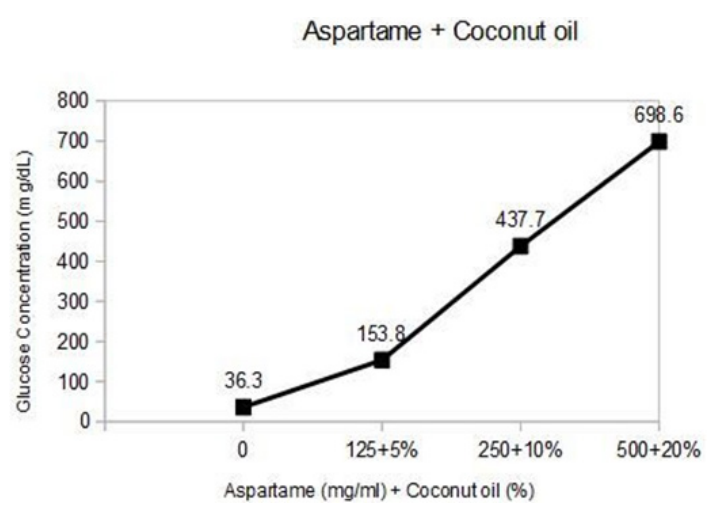

Graph 5 shows Glucose concentration in hemolymph with increasing concentration of a combination of aspartame and coconut oil.

Table 2. Rate of viability and glucose concentration measured in biochemical analysis of hemolymph using hexokinase method

\begin{tabular}{lcc}
\hline Concentration of compound & Rate of viability $(\%)$ & Glucose concentration $(\mathrm{mg} / \mathrm{dL})$ \\
\hline Negative control & 100 & 36.3 \\
$5 \%$ coconut oil & 99 & 40.2 \\
$10 \%$ coconut oil & 90 & 95.6 \\
$20 \%$ coconut oil & 10 & 357 \\
$5 \%$ oil $+2.5 \mathrm{~g}$ sugar & 100 & 631 \\
$10 \%$ oil $+5 \mathrm{~g}$ sugar & 50 & 875 \\
$20 \%$ oil $+10 \mathrm{~g}$ sugar & 20 & 1329 \\
$2.5 \mathrm{~g}$ sugar & 100 & 43.2 \\
$5 \mathrm{~g}$ sugar & 95 & 152.7 \\
$10 \mathrm{~g}$ sugar & 90 & 557 \\
$125 \mathrm{mg} / \mathrm{ml}$ of aspartame & 100 & 94.5 \\
$250 \mathrm{mg} / \mathrm{ml}$ of aspartame & 90 & 70.3 \\
$500 \mathrm{mg} / \mathrm{ml}$ of aspartame & 50 & 20.7 \\
$125 \mathrm{mg} / \mathrm{ml}$ of aspartame $+5 \%$ oil & 0 & 153.8 \\
$250 \mathrm{mg} / \mathrm{ml}$ of aspartame $+10 \%$ oil & 0 & 437.7 \\
$500 \mathrm{mg} / \mathrm{ml}$ of aspartame $+20 \%$ oil & 0 & 698.6 \\
\hline
\end{tabular}


Combination of aspartame and oil showed increase in glucose levels (Graph 5). This is attributed and confirmatory to the contribution of oil in elevating glucose levels. The viability of flies was $0 \%$ proving that the combination of oil and aspartame is not desirable and the effect of aspartame in reducing glucose levels is hindered by the presence of oil in diet.

\subsection{Danio Rerio}

\subsubsection{Fin Regeneration Assay}

The extent of fin regeneration was measured using image J software and the regenerative potential of the fins showed a marked decrease with increase in concentration of aspartame. Concentration of $20 \mathrm{mg} / \mathrm{ml}$ showed $50 \%$ reduction in fin regeneration compared to negative control. Both $10 \mathrm{mg} / \mathrm{ml}$ and $20 \mathrm{mg} / \mathrm{ml}$ showed lower regenerative capacity; indicating the toxicity of aspartame. The regenerative capacity was compared with EMS as the positive control. (Table 3) (Figure 3).

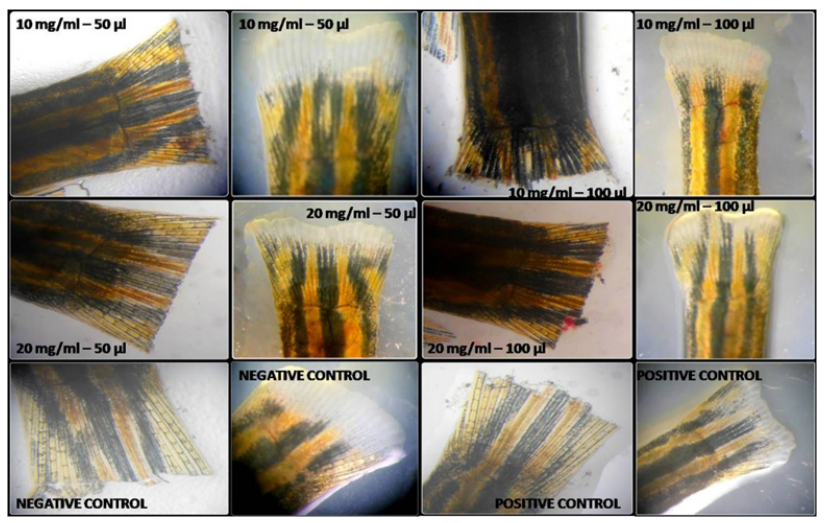

Figure 3. Fin regeneration assay in Danio rerio.

Legend: Left panel in each figure indicates image after wounding, Right panel indicates image after regeneration, for concentrations of $10 \mathrm{mg} / \mathrm{ml}$ and $20 \mathrm{mg} / \mathrm{ml}$ of aspartame in volumes of $50 \mu \mathrm{l}$ and $100 \mu \mathrm{l}$ each ; negative control and positive control.

Table 3. Length of fin regenerated for defined concentrations of test and control samples

\begin{tabular}{lc}
\hline CONCENTRATION OF & $\begin{array}{c}\text { LENGTH OF FIN } \\
\text { RSPARTAME }(\mathrm{mg} / \mathrm{ml})\end{array}$ \\
\hline Negative control & 3.040 \\
$10 \mathrm{mg} / \mathrm{ml}-50 \mu \mathrm{l}$ & 2.580 \\
$10 \mathrm{mg} / \mathrm{ml}-100 \mu \mathrm{l}$ & 1.120 \\
$20 \mathrm{mg} / \mathrm{ml}-50 \mu \mathrm{l}$ & 1.107 \\
$20 \mathrm{mg} / \mathrm{ml}-100 \mu \mathrm{l}$ & 0.910 \\
Positive control (EMS) & 0.643 \\
\hline
\end{tabular}

\subsection{DNA Fragmentation Assay}

A distinct marked increase in DNA fragmentation (observed as distinct shearing) was documented on $2 \%$ agarose with increase in concentration of aspartame. (Figure 4).

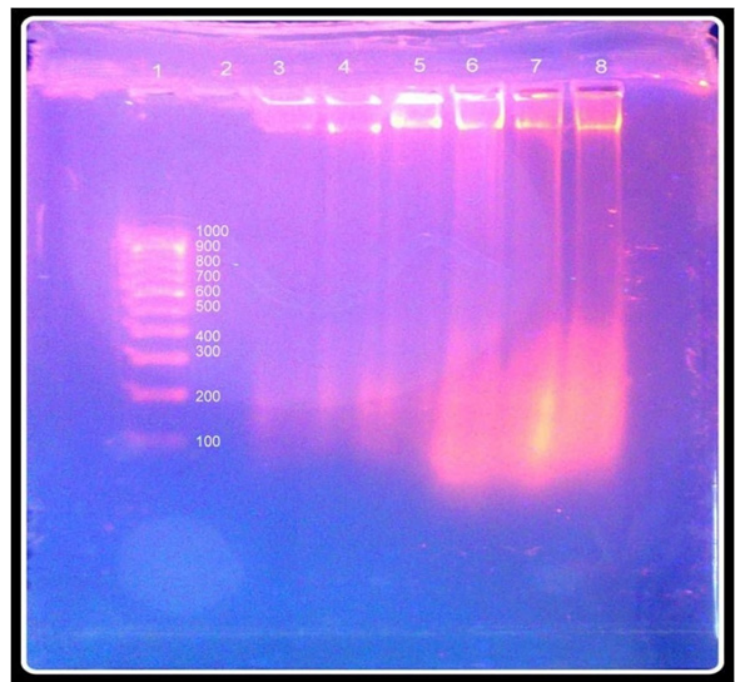

Figure 4. DNA fragmentation assay (Danio rerio).

Legend:

1 - DNA ladder

2 - Blank

3 - Negative control

$4-62.5 \mathrm{mg} / \mathrm{ml}$ of aspartame

$5-125 \mathrm{mg} / \mathrm{ml}$ of aspartame

$6-250 \mathrm{mg} / \mathrm{ml}$ of aspartame

$7-500 \mathrm{mg} / \mathrm{ml}$ of aspartame

8 - Positive control

\subsection{Embryo Toxicity Assay}

The embryos were observed for viability and phenotypic changes for 48 hours. Loss of activity was observed in embryos exposed to higher concentration of $250 \mathrm{mg} / \mathrm{ml}$ and $500 \mathrm{mg} / \mathrm{ml}(100 \mu \mathrm{l})$ by the end of 24 hours. On the second day, the embryos exposed to a concentration of 250 $\mathrm{mg} / \mathrm{ml}$, demonstrated severe hyperactivity coupled with marked neurological disturbances. Death was recorded by $48^{\text {th }}$ hour of exposure in $250 \mathrm{mg} / \mathrm{ml}$ concentration. $500 \mathrm{mg} / \mathrm{ml}$ recorded loss of activity followed by death in $50 \%$ of the embryos by 24 hours and the other $50 \%$ by 48 hours.

Inactivity was recorded at lower concentration of 62.5 $\mathrm{mg} / \mathrm{ml}$ and $125 \mathrm{mg} / \mathrm{ml}$ in 24 hours of exposure and 125 $\mathrm{mg} / \mathrm{ml}$ showed death by 48 hours. (Table 4 ). 
Table 4. Effect of aspartame on Danio rerio embryos

\begin{tabular}{lcc}
\hline Concentration of aspartame & Duration of exposure & Observation \\
\hline Negative control & 0 hours & No changes \\
& 24 hours & No changes \\
Positive control & 48 hours & No changes \\
& 0 hours & No changes \\
$62.5 \mathrm{mg} / \mathrm{ml}-500 \mu \mathrm{l}$ & 24 hours & $100 \%$ Slightly inactive \\
& 48 hours & $100 \%$ Dead \\
$125 \mathrm{mg} / \mathrm{ml}-500 \mu \mathrm{l}$ & 0 hours & No changes \\
& 24 hours & $100 \%$ Slightly inactive \\
& 48 hours & $50 \%$ Dead \\
$250 \mathrm{mg} / \mathrm{ml}-500 \mu \mathrm{l}$ & 0 hours & No changes \\
& 24 hours & $100 \%$ inactive \\
& 48 hours & $100 \%$ Dead \\
$500 \mathrm{mg} / \mathrm{ml}-500 \mu \mathrm{l}$ & 0 hours & No changes \\
& 24 hours & $100 \%$ inactive \\
& 48 hours & $100 \%$ Dead \\
& 0 hours & No changes \\
& 24 hours & $50 \%$ dead \\
\end{tabular}

\section{Discussion}

The wide spread use of aspartame as an artificial sweetener by general public, especially diabetics and obese individuals has been an issue of concern in health perspective. Its negative effects have been well studied in various animal models and researchers across the globe have been concerned about its neurological toxicity ${ }^{15-17}$. Aspartame is composed of phenylalanine (50\%), aspartic acid (40\%) and methanol (10\%). Phenylalanine and aspartic acid have their vital roles in neurotransmitter regulation, excitatory neurotransmitter in the central nervous system respectively. Methanol and its byproducts give rise to a number of toxic derivatives ${ }^{18,19}$.

In the present study we have evaluated the genotoxicity of aspartame in two animal models; Drosophila melanogaster (Phenotypic analysis and DNA fragmentation assay) and Danio rerio (Embryo toxicity, Fin regeneration and DNA fragmentation assay). The flies and fishes were exposed to 4 concentrations of aspartame (500 mg/ml, $250 \mathrm{mg} / \mathrm{ml}, 125 \mathrm{mg} / \mathrm{ml}, 62.5 \mathrm{mg} / \mathrm{ml}$ ). An important aspect that was considered was to measure the sugar levels (by biochemical analysis) in flies post exposure to aspartame and the same was compared with normal sugar intake and in combinations with coconut oil, sugar and aspartame. The fact of increasing blood glucose level and cholesterol levels has been a regular complaint amongst many diabetics and the usage of aspartame has also been higher in patients with diabetes. The present biochemical assay was carried out to compare and contrast the difference in glucose levels in flies exposed to increasing concentrations of sugar, oil, aspartame and combinations of sugar+ coconut oil, aspartame+ coconut oil. The results suggested marked phenotypic changes in flies and distinct shearing of DNA on DNA fragmentation assay in both flies and fishes. The extent of fin regeneration was also found to be reduced with increasing concentrations of aspartame. Embryo toxicity assay in zebra fish demonstrated inactivity, neurological disturbances followed by death. The biochemical analysis revealed the efficiency of aspartame to decrease glucose levels in hemo lymph of flies but the presence of oil hindered the efficacy of aspartame to reduce the glucose levels. Marked genotoxicity has been demonstrated in both animal models. In vitro genotoxicity assessment has demonstrated that aspartame has significantly induced chromosomal aberrations and micro nucleus formation and also showed cytotoxicity by decreased mitotic index.

\section{Conclusion}

The safety of aspartame has always been a topic of controversy and there are varied views regarding its usage. Studies conducted 'hitherto' have reported that intake of aspartame could cause neurological and behavioral disturbances in susceptible individuals. Research studies in the past have demonstrated that aspartame interferes with metabolism of amino acids and in turn disturbs 
protein structure and metabolism as well. Research studies on rats have shown that the neuronal function and endocrine balances have been severely compromised owing to loss of integrity of nucleic acids. Studies have proved that aspartame and its metabolic breakdown byproducts cause increased neuronal depolarization thus compromising ATP supply to enzyme reactions leading to truncated enzyme activities ${ }^{13,14,19}$.

In the present study we have evaluated the genotoxicity of aspartame in two animal models; Drosophila melanogaster (Phenotypic analysis and DNA fragmentation assay) and Danio rerio (Embryo toxicity, Fin regeneration and DNA fragmentation assay). The flies and fishes were exposed to 4 concentrations of aspartame (500 mg/ml, $250 \mathrm{mg} / \mathrm{ml}, 125 \mathrm{mg} / \mathrm{ml}, 62.5 \mathrm{mg} / \mathrm{ml}$ ).

The in vivo genotoxicity (of the present study) is consistent with results of the in vitro assessment conducted 'hitherto ${ }^{20-23}$. Apart from genotoxic potential assessment, the present study has shown decreased glucose levels on consumption of aspartame. Combinations of oil with sugar and aspartame have demonstrated marked increase in glucose levels. This is attributed and confirmatory to the contribution of oil in elevating glucose levels. The viability of flies was $0 \%$ proving that the combination of oil and aspartame is not desirable and the effect of aspartame in reducing glucose levels is hindered by the presence of oil in diet. It is prelude to understanding the undesirable biochemical effect of aspartame in combination with oil. The study concludes on the in vivo genotoxic potential of aspartame and its consumption in combination with oil as undesirable.

\section{References}

1. Iyyaswamy A, Rathinasamy S. Effect of chronic exposure to aspartame on oxidative stress in the brain of albino rats. J Biosci. 2012 Sep; 37(4):679-88.

2. Lim U, Subar AF, Mouw T, Hartge P, Morton LM, Zenberg-Solomon R, Campbell D, Hollenbeck AR, Schatzkin A. Consumption of aspartame-containing beverages and incidence of hematopoietic and brain malignancies. Cancer Epidemiol Biomarkers Prev. 2006 Sep; 15(9):1654-9.

3. Soffritti M, Belpoggi F, Esposti DD, Lambertini L. Aspartame induces lymphomas and leukaemias in rats. Eur J Oncol. 2005 Jun; 10(2):107-16.

4. Humphries P, Pretorius E, Naude H. Direct and indirect cellular effects of aspartame on the brain. European Journal of Clinical Nutrition. 2008; 62:451-62.

5. Maher TJ, Wurtmant RJ. Possible neurologic effects of aspartame, a widely used food additive. Environmental health perspectives. 1987 Nov; 75(11):53-7.
6. Rencuzogulları E, Tuylu BA, Topaktas M, Basri I'la H, Kayraldiz A, Arslan M, Diler SB. Genotoxicity of aspartame. Drug and Chemical Toxicology. 2004 Aug; 27(3):257-68.

7. Holder MD. Behavioral assessment of the toxicity of aspartame. Pharmacology, Biochemistry and Behaviour. 1989 Jan; 32(1):7-26.

8. Soffritti M, Belpoggi F, Manservigi M, Tibaldi E, Lauriola M, Falcioni L, Bua L. Aspartame administered in feed, beginning prenatally through life span, induces cancers of the liver and lung in male Swiss mice. American Journal of Industrial Medicine. 2010 Dec; 53(12):1197-206.

9. Park $\mathrm{CH}$, Coi SH, et al. Glutamate and aspartate impair memory retention and damage hypothalamic neurons in adult mice. Toxicology letters. 2000 May; 115(2):117-25.

10. Moller SE. Effect of aspartame and protein, administered in phenylalanine-equivalent doses on plasma neutral amino acids, aspartate, insulin and glucose in man. Pharmacology and toxicology. 1991 May; 68(5):408-12.

11. Wolraich ML, Lingren SD, et al. Effects of diets high in sucrose or aspartame on the behavior and cognitive performance of children. New England journal of medicine. 1994 Feb; 330(5);301-7.

12. Koehler SM, Glaros A. The effect of aspartame on migraine headache. Headache: Journal of Head and Face pain. 1988 Feb; 28(1):10-4.

13. Newman MD, Cohen JS, Seymour Solomon MD, Lipton RBMD, Lawrence MDC. Aspartame as a dietary trigger of headache. Headache: The Journal of head and face pain. 1989 Feb; 29(2):90-2.

14. Kiritsy PJ, Maher TJ. Acute effects of aspartame on systolic blood pressure in spontaneously hypertensive rats. Journal of Neural Transmission. 1986 Jun; 66(2):121-8.

15. Kulczycki A, Jr. Aspartame-induced Uricaria. Annals of internal medicine. $1986 \mathrm{Feb} ; 104(2): 207-8$.

16. Caballero B, Mahon BE, Rohr FJ, Levy HL, Richard J, Wurtman MD. Plasma amino acid levels after single dose aspartame consumption in phenylketonuria mild ii hyperphenylalaninemia and heterozygous state for phenylkeonuria. The Journal of pediatrics. 1986 Oct; 109(4):668-71.

17. Maher TJ, Wurtman RJ. Possible neurologic effects of aspartame, a widely used food additive. Environmental health perspective. 1987 Nov; 75:53-7.

18. Barua J, Bal A. Emerging facts about aspartame. The Journal of the Diabetic Association of India. 1995; 35(4):1-15

19. Ferguson JM. Interaction of aspartame and carbohydrates in an eating disordered patient. The American journal of psychiatry. 1985 Feb; 142(2):71-81.

20. Poss KD, Keating MT, Nechiporuk A. Tales of Regeneration in Zebra fish. Developmental Dynamics. 2003 Feb; 226(2):202-10.

21. Braunbeck T, Lammer E. Fish embryo toxicity assays. 2006 Mar.

22. Na J, Musselman LP, Pendse J, Baranski TJ, Bodmer R, Ocorr K, Cagan R. A Drosophila model of high sugar diet-induce cardiomyopathy. PLOS Genetics. 2013 Jan; 9(1): e1003175.

23. Heinrichsen ET, Haddad GG. Role of high-fat diet in stress response of Drosophila. 2012 Aug; 7(8):e42587. 